\title{
Portraits of Jesus
}

\section{Studies in Christology \\ Ed. by Susan E. Myers}

[Das Bild Jesu. Christologische Studien.]

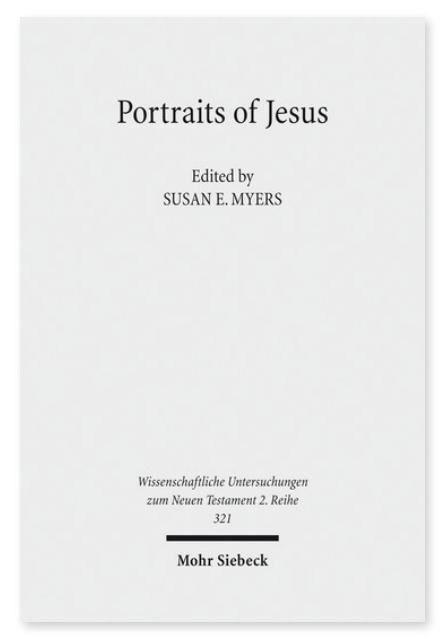

2012. XX, 460 Seiten. WUNT II 321

ISBN 978-3-16-152027-3

DOI 10.1628/978-3-16-152027-3

eBook PDF 104,00€

ISBN 978-3-16-151795-2

fadengeheftete Broschur 104,00€
Veröffentlicht auf Englisch.

Die Autoren dieser Sammlung von Aufsätzen untersuchen das Verständnis von Jesus in verschiedenen frühchristlichen Schriften. Einige Texte setzen sich mit der Darstellung Jesu in den Evangelien des Johannes und des Markus, sowie in den Briefen an die Hebräer und den Paulusbriefen auseinander. Weitere frühchristliche Literatur, vom Kindheitsevangelium des Thomas bis zu verschiedenen apokryphen Apostelgeschichten und liturgischen oder anderen Gebetstexten, wird ebenfalls dargestellt, während einige andere Texte sich mit einer Auswahl antiker Literatur, sowohl christlicher als auch nicht christlicher, befassen. Die Autoren beleuchten mit einer Vielfalt von Blickwinkeln und Methoden die Art und Weise, mit der die Autoren der antiken Texte sich mit der Bedeutung Jesu, ebenso wie mit ihren Quellen, ihren Gesprächspartnern und Kritikern beschäftigten.

Inhaltsübersicht

Susan E. Myers: Introduction

Part I: Portraits of Jesus in Gospel Literature

George L. Parsenios: A Sententious Silence: First Thoughts on the Fourth Gospel and the Ardens Style - Joshua Ezra Burns: Like Father, Like Son: An Example of Jewish Humor in the Gospel of John - Stephen P. Ahearne-Kroll: The Scripturally Complex Presentation of Jesus in the Gospel of Mark - Jeremy F. Hultin: Disobeying Jesus: A Puzzling Element in the Messianic Secret Motifs - Timothy Luckritz Marquis: Crucifixion, State of Emergency, and the Proximate Marginality of Christ's Kingship Stephen J. Davis: Bird Watching in the Infancy Gospel of Thomas: From Child's Play to Rituals of Divine Discernment

Part II: Portraits of Jesus in Paul

Gregory E. Sterling: „The Image of God«: Becoming Like God in Philo, Paul, and Early Christianity - Judith M. Gundry: JesusTradition and Paul's Opinion About the Widow Remaining as a Widow (1 Cor 7:40) - Emma Wasserman: "An Idol is Nothing in the World « (1 Cor 8:4): The Metaphysical Contradictions of 1 Corinthians 8:1-11:1 in the Context of Jewish Idolatry Polemics Thomas H. Tobin, S.J.: The Use of Christological Traditions in Paul: The Case of Rom 3:21-26

Part III: Portraits of Jesus in Prayer and Liturgy

Paul F. Bradshaw: The Status of Jesus in Early Christian Prayer Texts - Susan E. Myers: Praying to Jesus in the Acts of Thomas Bryan D. Spinks: Handing on Tradition: Some Themes and Images in the Maronite Baptismal Ordo

Part IV: Portraits of Jesus in Other Early Christian Literature

Joshua D. Garroway: A New Sort of Priest for a New Sort of People: Hebrews as an Interpretation of Romans - Candida R. Moss: Standing at the Foot of the Staircase: Christology and Narrative Structure in the Prologue to Hebrews (Heb 1:1-4) Daniel C. Harlow: Born of Fornication: The Jewish Charge of Jesus' Illegitimacy in John, Celsus, and Origen - Richard I. Pervo: Shepherd of the Lamb: Paul as a Christ-Figure in the Acts of Paul - Dylan M. Burns: Jesus' Reincarnations Revisited in Jewish Christianity, Sethian Gnosticism, and Mani - Michael Peppard: Archived Portraits of Jesus: Unorthodox Christological Images from John and Athanasius

Susan E. Myers Born 1958; PhD from University of Notre Dame in Christianity and Judaism in Antiquity; currently Associate Professor in the Theology Department at the University of St. Thomas, St. Paul, MN, USA.

Jetzt bestellen:

https://mohrsiebeck.com/buch/portraits-of-jesus-9783161520273?no_cache=1

order@mohrsiebeck.com

Telefon: +49 (0)7071-923-17

Telefax: $+49(0) 7071-51104$ 